\title{
The Transfer of Character Education Value in Children Literature: A Version of Indonesian and Translation Literature
}

\author{
Nur Azmi Alwi ${ }^{1}$, Harris Effendi Thahar ${ }^{2}$, Yasnur Asri ${ }^{3}$, Atmazaki ${ }^{4}$ \\ ${ }^{1234}$ Univesitas Negeri Padang, Padang - Indonesia, (nurazmi_alwi@yahoo.com)
}

\begin{abstract}
This study aims at explaining the transfer of character education value in children literature in terms of Indonesian and translation version. This study was a qualitative research using descriptive method. The data in this study encompassed the value of character education which were explored from the narrator, characters' utterance and characters' act. There were two novels as the source of data, namely Laskar Pelangi as Indonesian literature and Nenek Hebat dari Saga as translation literature. The form of data inventory was used for collecting data. Three steps were employed to analyze data, which were: data reduction, data display and conclusion. The finding of study indicated that there was the transfer of character education value through children literature in terms of the behavior and attitude. These values closely related to (1) God, (2) self, (3) family, (4) society and nation, and (5) environment. In Laskar Pelangi's novel, there were sub indicators especially in terms of Islam teaching, which are: discipline, creative, workhard, honesty, tolerance and nationalism. In Nenek Hebat dari Saga's novel, there were some sub indicators related to behavior such as Buddhism, wise, efficient, creative, and confident. This novel also described closely the habit, culture and nature of Japanese.
\end{abstract}

Keywords: children literature, character education value, indonesian literature and translation literature.

\section{Introduction}

Character education in elementary school has a strategic role as the basis in preparing students to get success and has self-integrity. In this context, character education can be conducted through integrating the cognitive, affective, and psychomotor aspects. Lickona (2012) states that character education will not effective without integrating the three aspects, which are: moral reasoning, moral feeling, and moral action. Character education that is applied in integrated and sustainable way can make children becoming smart in emotion. Literature has strong relevancy with character education mission. The study of literature is impressed as moral and value learning. Even though literature is not the study about ethic and moral, but there is an ideal understanding and character as stated in moral value of the story and modeled by the characters in the story.

Literature has a big potential to lead the society into a changing, including the changing in character. Even though the literature has the function to entertain but there is still an education value in it. In this context, Children literature is one of genres in the literary work which is created imaginatively based on the child's view. It may tell anything about the life which is appropriate with 
child's logic and emotion. Children literature can be directed to teach moral values and explore issues of philosophy.

In relating to its function as the media in delivering the moral values, literature can reflect the human mental experience in the level of human niveau, the feeling of pity, differentiating good and bad things, helpful, etc. This mental experience is realized in form of mental conflict experienced by the characters in the story and of word choice used to express feeling and idea. In other side, when literature contains a moral value and life concept, it cannot be expressed directly, but through the character's idea, attitude, and action (Nurgiyantoro, 2010:32). In short, literature can be used as the media in transmitting idea and value for people (its reader). In this point, literature functions to realize the character education.

Children literature is potential in developing the understanding of children about human's behavior. By reflecting the human life, literature has the power to form someone's life experience (vicarious experience). Human life experience focuses on one aspect or one period in individual life which gives understanding to the reader about something that he/ she never felt before. Children's story about certain group, like primitive group and the exotic life of a group gives a deep understanding for children about the life of society outside the community. Through introducing literature to students, their empathy can be developed to understand the variety and universal of human life (O'Sullivan, 2004). The more the children know the life experience from the internalization of the story, the stronger the value of empathy to others.

The existence of children literature consistently grows in Indonesia. Through the publishers such as Penerbitan Missionaris (Missionary Publishing), Percetakan Negara (Country Publishing), Penerbitan Swasta Belanda (Colonial Private Publishing), Penerbitan Cina Peranakan (Chinese Origin Publishing), and Penerbitan Pribumi (Pribumi Publishing) in 1908-1945 are found various children stories in Javanese, Sundanese, Malays, Madura, Batak, Balinese, and Kaili language. Some religious stories, stories in the setting of Chinese culture, biography, and translation literature were popular at that time. Even, in 1800s, there was a story which was written for children only. Motivated by the awareness of society about the importance of culture and nation awareness, the translation literary works such as Hikayat Sinbad (The Legend of Sinbad), Robinson Crusoe, Kisah 1001 Malam (The Legend of 1001 Nights), and Mengelililingi Boemi dalam 80 Hari (Surrounding the Earth in 80 Days), and Lamanja were provided for Indonesian children in 1800s.

The consistency and spread of children literature in Indonesia are also encouraged by the development of information and technology. During the development, children literature is not only served in form of text or book but also in form of online portal. Each individual can write children literature creatively and spread it to be accessed in public. Based on the perspective of character education, children literature contains of values that can be transmitted by the author to the children as the main reader. Values in this context refer to something that is appreciated, regarded and inherited to the next generation (Nair, 2009).

The value priority that must be inherited to the next generations is influenced by social and cultural aspect where they live. The understanding of value concept also needs the understanding about society and culture that support the value. Thus, each person will act following the value criteria that become a convention in a society. The support and tendency toward certain values are also found in children literature for both Indonesian and translation version.

\section{Method}

This research is a qualitative research which focuses on the values of character education in Indonesian and translation children literature. The value of character education in children literature becomes the data of the research. The source of data encompassing Andrea Hirata's Laskar Pelangi 
(2007) as Indonesian children literature, and Yoshichi Shimada's Nenek Hebat dari Saga (2011)as translation version.The data is collected using the following steps: choosing and selecting, marking, identifying, and interpreting the data related with character education in Indonesian and translation children literature (Miles dan Huberman, 1992). Three steps are used to analyze the data, which are: (1) data reduction, (2) data display, and (3) concluding.

\section{Finding and Discussion}

Samani and Hariyanto (2011:46-47) state that the definition of real character education refers to behavior. The behavior can be classified into five indicators which are related to: (1) God, (2) self, (3) family, (4) society, and (5) environment. Based on these five indicators, the transfer of education value in Indonesian and translation version of children literature can be explained. The following is the explanation of each indicator.

1. The comparison of transfer of education value in children literature of Indonesian and translation version related to God

The indicator which is related to God can be elaborated into the sub indicators, encompassing religious, discipline, thinking beyond, be grateful, forgiving (Samani and Hariyanto, 2011:47). The data analysis shows that the transfer of value in relation to God (religious value) is found in Indonesian and translation version of children literature. Indonesian version of children literature is the representation of Indonesian children's behavior and directly related to Indonesian's culture. In the novel of Laskar Pelangi, the readers find the character education related to God. The same value is also found in the translation children literature. The following data indicates such value.

Tabel 1: The Comparison of Religious Value in the Novel of Laskar Pelangi and of Nenek Hebat dari Saga

\begin{tabular}{|c|c|c|}
\hline Num. & Religious Value in the novel of Laskar Pelangi & Religious value in the novel of Nenek Hebat dari Saga \\
\hline & $\begin{array}{l}\text {... nanti setelah aku pandai membaca huruf } \\
\text { arab, aku tahu bahwa tulisan itu berbunyi } \\
\text { amar makruf nahi mungkar artinya } \\
\text { "menyuruh kepada yang makruf dan } \\
\text { mencegah dari yang mungkar", itulah } \\
\text { pedoman utama warga Muhammadiyah. } \\
\text { (... later after I can read Arabic language, I } \\
\text { know that the words state amar makruf nahi } \\
\text { mungkar" which mean "asking to do right } \\
\text { things and avoiding from doing bad things", } \\
\text { that is the guidance of Muhammadiyah } \\
\text { citizens). } \\
\text { :Hiduplah hanya dari ajaran Al-Qur'an, } \\
\text { hadist dan Sunatullah, itulah pokok } \\
\text { tuntunan Muhammadiyah. } \\
\text { (Live based on the teaching from Alqur'an, } \\
\text { hadist and Sunatullah, that is the main } \\
\text { teaching of Muhammadiyah). }\end{array}$ & $\begin{array}{l}\text { Kemudian, seberapa pun kami miskinnya kami, } \\
\text { Nenek tidak pernah pelit untuk sumbangan ke kuil } \\
\text { ataupun segala keperluan lain yang berhubungan } \\
\text { dengan Buddha. } \\
\text { Aku sampai berpikir, kalau sampai ada yang } \\
\text { mencatat Nenek berdosa hanya karena berpesta } \\
\text { satu kali dalam satu tahun dengan festival } \\
\text { makanannya, maka mungkin dewa itulah yang } \\
\text { tidak memilkiki hati Buddha. } \\
\text { (Then, even though we are poor, Grandma never be } \\
\text { stingy in giving the contribution to the temple or } \\
\text { for the need related with Budha. } \\
\text { I ever think that, if Grandma is blamed to have a } \\
\text { sin just because she has a festival once in a year by } \\
\text { her food festival, the idol indeed have no the } \\
\text { Buddhism's heart) }\end{array}$ \\
\hline
\end{tabular}

Based on the table above, it can be understood that there is a different root of value which is transferred by the two novels. The religious value in the novel of Laskar Pelangi is based on Islamic teaching. Meanwhile, the religious value in the novel of Nenek Hebat dari Saga relates to 
Buddhism. Nevertheless, both of these novels contain religious values in term of different culture and source.

2. The comparison of education transfer value in Indonesian and translation version of children literature in indicator related with self

The value related with self can be elaborated into several sub indicators: hard work, brave, mature, wise, persevering, careful, individual, confident, creative, distinct, and trusteeship (Samani and Hariyanto, 2011:47). Based on data analysis, it is found that there is a value transfer related with self-potency in Indonesian and translation version of children literature. It can be seen in the following quotation.

Tabel 2: The Comparison of Self Potential Valuein the Novel of Laskar Pelangi and of Nenek Hebat dari Saga

\begin{tabular}{|c|c|c|}
\hline Num. & $\begin{array}{l}\text { Self potential value in the novel of } \\
\text { Laskar Pelangi }\end{array}$ & $\begin{array}{l}\text { Self potential value in the novel of Nenek } \\
\text { Hebat dari Saga }\end{array}$ \\
\hline & $\begin{array}{l}\text {...namun tak sehari pun ia pernah bolos... } \\
\text { (but he never absent from school) } \\
\text { "Tapi lebih dari setengah perjalanan sudah, } \\
\text { aku tak kan kembali pulang gara-gara } \\
\text { buaya bodoh ini. Tak ada kata bolos dalam } \\
\text { kamusku..." } \\
\text { (However, it is already the half of the } \\
\text { route, I will not come back home } \\
\text { because of this stupid crocodile. There } \\
\text { is no absent for school in my own } \\
\text { dictionary) } \\
\text { "Lintang bereskperimen merumuskan } \\
\text { metode jembatan keledainya sendiri untuk } \\
\text { pelajaran-pelajaran hafalan.." } \\
\text { (Lintang conducts an experiment to } \\
\text { formulate his own shortcut methods } \\
\text { for the lesson). }\end{array}$ & $\begin{array}{l}\text { Namun bagiku, saat makan siang sekolah justru } \\
\text { kesempatan bersantap mewah dan lengkap sehat } \\
\text { lima sempurna. Aku bisa tambah lima- enak kali } \\
\text { susu skim yang tidak mau diminum murid lain } \\
\text { dengan alasan tak berbau enak. Roti gulung yang } \\
\text { kata mereka, "Keras, tidak mau," aku bawa pulang } \\
\text { dengan menjejalkannya ke dalam ransel, meski itu } \\
\text { berarti mesti mengeluarkan semua buku teks dari } \\
\text { sana. } \\
\text { Roti gulung yang aku bawa pulang itu kalau } \\
\text { dipanggang di atas arang, akan menebarkan wangi } \\
\text { enak ke seluruh rumah. } \\
\text { (However, for me, having a lunch at school is } \\
\text { the time to have a luxury and complete feast. I } \\
\text { can drink milk that other students do not want } \\
\text { because of the smell. I take the roll- bun, that } \\
\text { they said "It is hard, I don't want it", I bring it } \\
\text { home and put it into my backpack even } \\
\text { though I have to pull out all my textbooks. } \\
\text { The roll-bun that I bringwill spread delicious } \\
\text { smell if I bake it on the charcoal. }\end{array}$ \\
\hline
\end{tabular}

The quotation above indicates that there is an education value in term of self-potency that is realized by the character. In the novel of Laskar Pelangi, it is found the value of discipline, creative and hard work. Based on the quotation, it shows that the character is never absent to go to school. He also shows the discipline and creative manner in the learning activity. The value of hardworking is also found in the story. It is indicated through the character's action to pass the path to arrive at school even though the crocodile blocks the path. In the novel of Nenek Hebat dari Saga, the value of self-potency is found through the wise, efficient and creative attitude. These values are indicated through the character's action when he reprocesses the roll-bun from school to be a delicious food.

3. The comparison of education transfer value in Indonesian and translation version of children literature in indicator related with family 
The indicator of family can be elaborated into several sub indicators: working-hard, carefulness, think ing beyond, confidence, sportive attitude, affection and orderly (Samani and Hariyanto, 2011:47). Data analysis indicates that the value in relation to family is transmitted in the children literature of Indonesian and translation version as stated in the following quotation:

Tabel 3: The Comparison of Family Valuein the Novel of Laskar Pelangi and of Nenek Hebat dari Saga

\section{Num. Family value in the novel of Laskar Family value in the novel of Nenek Hebat Pelangi dari Saga}

karena pelajaran Budi Pekerti "Nek, kita memang miskin sekarang, tapi suatu Kemuhammadiayahan setiap Jum'at pagi hari nanti enak juga ya kalau bisa jadi kaya." Tanpa tak membolehkan aku membohongi diduga- duga, beginilah jawaban Nenek. orang tua apalagi ibu"

(...because one of the lesson that I got from the subject of ethic on Friday morningsforbids me lie to parents especially to mother")

"Kau ini bicara apa? Ada dua jalan buat orang miskin.

"Miskin muram dan miskin ceria.

“Kita ini miskin ceria.

"selain itu karena bukan baru- baru ini saja menjadi miskin, kita tidak perlu cemas.

“Tetaplah percaya diri.

"Keluarga kita memang turun- temurun miskin.

("Grandma, we are poor now, but someday it will be pleasant to be rich" without any estimation, this is the answer from Grandma.

"What are you talking about? There are two ways for poor people".

"gloomy poor and happy poor"

"we are a happy poor"

"besides, we are poor not from yesterday, so do not worry"

"be confident"

"our family poor is inherit"

Based on the table above, it can be understood that the character value related with family as described in Laskar Pelangi's novel is about honesty. Ikal applies the subject of ethic that he has learnt when speaks to his mother. Even though he takes a risk by getting laugh but he still becomes honest. Beside, in Nenek Hebat dari Saga's novel, there is value about family education that is described through sub indicator of confident. Based on the quotation, the character is advised to 
be confident even though he is from a poor family. Grandma explains her grandson to do the best thing in live and not to be worry.

4. The comparison of education transfer value in Indonesian and translation version of children literature in indicator related with society

The indicator of behavior related to society is elaborated into several sub indicators: culture, tolerance, nationalism, and consideration (Samani and Hariyanto, 2011:47). The data indicates that that there is a transfer of value related to society in the novels. It can be seen from the following quotation.

Tabel 4: The Comparison of Society Valuein the Novel of Laskar Pelangi and of Nenek Hebat dari Saga

No. Society value in the novel ofLaskar Pelangi
....dengan demikian ajang ini disebut sebagai
media tempat empat komponen utama
kelompok subetnik di kampong kami, orang
Tionghoa, orang Melayu, orang pulau
bersarung, dan orang Sawang berkumpul..
(...thus, this event is christened as the media
of four main groups of sub-ethnic in our
village: Tionghoa people,Malay, Pulau
Bersarung people and the gathering of Orang
Sawang)
"Saat itu adalah pelajaran seni suara dan dia
begitu bahagia karena masih sempat
menyanyikan lagu "Pada mu Negeri" di
depan kelas.
(That time is the art education lesson and he is
so happy because he can sing the song
"Padamu Negeri" in front of the class).

Society value in the novel of Nenek Hebat dari Saga Sebagai contoh benda pungutan yang Nenek maksudkan ini, antara lain supermarket khusus kami tentunya. Ditambah lagi festival makanan setahun sekali.

Yaitu acara obon, festival musim panas.

Di area Kyushu, obon selalu dilaksanakan di hari terakhir festival. Untuk mengantarkan roh yang berpulang kembali ke Buddha, anggota keluarga yang ditinggalkan menghanyutkan perahu yang membawa makanan dan bungan di atasnya ke sungai. Ritual ini bernama shouryou nagashi.

(as the example of picking things that Grandma talks about is the supermarket for poor people like us and also the feast festival once a year, that is Obon summer festival.

In Kyushu, Obon is always done in the last day of the festival.To lead the dead spirit back to Buddha, the left family send the boat with food and flower in it. This ritual named shouryou nagashi).

Based on the table above, it can be understood that there is value of education character that relates to society. The Laskar Pelangi's novel describes the value of tolerance among heterogeneous society. People who have different background in terms of social and cultural aspect should create a harmonious relationship. Besides, the soul of nationalism is indicated through singing a national song. In Nenek Hebat dari Saga, there is a situation related to society's habit in Japan culture named Obon festival. This festival is aimed at leading the dead spirit to go back to Buddha. In such ritual, the left family sends the boat with food and flower in it. This ritual named shouryou nagashi.

5. The comparison of education transfer value in Indonesian and translation version of children literature in indicator related with environment

The indicator of behavior related to environment is elaborated into several sub indicators: thinking beyond, caring to nature, and appreciating the health (Samani and Hariyanto, 2011:47). Based on the data analysis, it is found that there is a value transfer related to environment in the novels as indicated below: 
$<$ NUR AZMI ALWI, HARRIS EFFENDI THAHAR, YASNUR ASRI, ATMAZAKI >

Tabel 5: The Comparison of Environment Valuein the Novel of Laskar Pelangi and of Nenek Hebat dari Saga

\begin{tabular}{|c|c|c|}
\hline No. & $\begin{array}{l}\text { Environment value in the novel of Laskar } \\
\text { Pelangi } \\
\text { Lintang yang sudah bisa menjadi kuli kopra dan } \\
\text { anak-anak perempuannya yang mengumpulkan } \\
\text { kerang saat angin teduh musim selatan } \\
\text { (Lintang can be Kopra laborer and his } \\
\text { daughtera pick cockle shells up when the calm } \\
\text { wind of south season) }\end{array}$ & $\begin{array}{l}\text { Environment value in the novel of Nenek Hebat dari } \\
\text { Saga } \\
\text { Ternyata Nenek biasa mengumpulkan ranting atau batang } \\
\text { pohon yang tersangkut di galah tersebut, } \\
\text { mengeringkannya, kemudian menggunakannya sebagai } \\
\text { kayu bakar. } \\
\text { "Selain sungai jadi bersih, kita mendapatkan bahan } \\
\text { bakar secara cuma- cuma. Sekali dayung dua- tiga pulau } \\
\text { terlampaui," ucap Nenek sambil tertawa keras. } \\
\text { (Grandma can pick the branches up that stucks in the } \\
\text { punting pole, dry and use them as the fire woods. } \\
\text { "it does not only to make the river cleans but also give } \\
\text { us free fire wood", said Grandma while laughing" }\end{array}$ \\
\hline
\end{tabular}

The quotation above indicates that both of children literatures in the version of Indonesian and translation version contain the value of character education in relating to environment aspect. In the Laskar Pelangi, there is a value related to environment as shown through the character and plot of the story. The setting of the story is Bangka Belitung as the area which has copra and shells. In line with it, the novel of Nenek Hebat dari Saga also describes the nature and environment of Japan where the river is surrounded by the trees. Grandma cleans the river by picking the branches in the river and uses them as the fire wood.

\section{Conclusion}

It is concluded briefly that there are five indicators of character education that can be transfered from Indonesian and translation children literature. These five character education values related to, (1) God, (2) self-potency, (3) family, (4) society, and (5) environment. Moreover, there are sub indicators that are described from the character in the novels. In Laskar Pelangi's novel, there are sub indicators in term of Islam teaching, which are: discipline, creative, work-hard, honesty, tolerance and nationalism. In Nenek Hebat dari Saga's novel, there are some sub indicators related to behavior such as Buddhism, wise, efficient, creative, and confident. This novel also describes closely the habit, culture and nature of Japanese.

\section{References}

Lickona, Thomas. (2012). Educating for Character. Jakarta: Bumi Aksara.

LongmanDictionaryofContemporaryEnglish .(1998).New England:LongmansGroup.

MerriamWebster's EncyclopediaofLiterature. (1995). Massachusetts: Springfield.

Miles, Matthew and Huberman, A. Michael. (1992). Qualitative Data Analysis.Jakarta:UI Press.

Nair, L Ramesh. (2009). "Gender in the Children Litetarature of Malaysia". A Dissertation. Malaysia: UPM.

Nurgiantoro, Burhan. (2005). Children Literature: An Introduction to Understand the Children World.Yogyakarta: Gajah Mada University Press.

O'Sullivan, S. (2004). “Books to live by: Using children's Literature for Character Education”. Reading Teacher, 57 (7), 640-645.

The Article of 20 in the Year of 2003 on the National Education System.(2006). Jakarta: SinarGrafika Publishing. 